\title{
The industrial relations chameleon: collective bargaining in the facility management business
}

\author{
Alejandro Godino and Oscar Molina \\ Centre d'Estudis Sociologics sobre la Vida Quotidiana i el Treball (QUIT), \\ Autonomous University of Barcelona, Bellaterra, Spain
}

Industrial relations in facility management

Received 4 December 2020

Revised 16 June 2021 1 October 2021

Accepted 17 November 2021

\begin{abstract}
Purpose - The paper aims to analyze collective bargaining in the facility management business of these six countries to explore similarities and differences between them. The analysis serves to test the differential impact of the national institutional setting on the protection provided by collective agreements to facility management workers.

Design/methodology/approach - The paper adopts a case study methodology to approach a facility management multinational company providing services in six European countries (France, Italy, The Netherlands, Poland, Spain and the UK) that represent different industrial relations systems with variance in key dimensions of collective bargaining, including its structure, coverage and extension of agreements.

Findings - The extension of the facility management business model has not always adopted a high-road strategy aimed at enhancing the quality and efficiency through the integrated management and delivery of services, which is expected to positively impact employment conditions. Rather, it has, in many cases, been a deliberate, low-road attempt to undercut working standards, taking advantage of the multiple services provided by the company in a context of growing de-centralization in collective bargaining. The results point to an important role of industrial relations institutions in shaping facility management strategies and outcomes.

Originality/value - Similar to other forms of outsourcing, facility management leads to fragmented employment relations. However, the concentration of outsourced workers under the same supplier organization introduces opportunities to ensure the protection of workers, depending on the adoption of a high- or low-road competitive strategy. This paper provides for the first time comparative evidence about industrial relations in facility management businesses, a largely under-researched area.
\end{abstract}

Keywords Outsourcing, Employee relations, Industrial relations, Collective bargaining, Case studies, Trade unions

Paper type Research paper

\section{Introduction}

The outsourcing of companies' activities not only has become a defining trait of post-Fordist organizations but also has experienced an important diversification in its mechanisms, the actors involved and its outcomes (Harrison and Kelley, 1993). Currently, we are witnessing

(C) Alejandro Godino and Oscar Molina. Published by Emerald Publishing Limited. This article is published under the Creative Commons Attribution (CC BY 4.0) license. Anyone may reproduce, distribute, translate and create derivative works of this article (for both commercial and non-commercial purposes), subject to full attribution to the original publication and authors. The full terms of this license may be seen at http://creativecommons.org/licences/by/4.0/legalcode

The authors would like to thank the research team of the "Relaunching Collective Bargaining Coverage in Outsourced Services - RECOVER" project. The authors also thank Maarten Keune for his valuable insights in the early idea of this article.

Funding: This study received funding support from European Commission, DG Employment, Social Affairs and Inclusion (Award Number: VS/2016/0351).

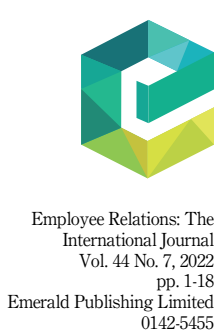

DOI 10.1108/ER-12-2020-0526 
ER

44,7

the extension of new modalities and mechanisms based on the opportunities opened by new technologies, including the growth of (bogus) self-employment, crowd employment through platforms and the expansion of facility management (FM) companies, among others (Drahokoupil, 2015). It is increasingly common to find companies relying on several of these mechanisms, depending on the characteristics of the activities outsourced. Moreover, it is not rare to observe provider companies further outsourcing some of the services/activities they provide to clients, therefore contributing to a cascading outsourcing effect. Together, these developments have contributed to blurring organizational boundaries and have made organizational structures increasingly complex.

The changing and varied nature of outsourcing practices is a result of several factors, including companies' characteristics, the sectoral context, the introduction of new technologies facilitating remote control and work and the institutional and regulatory environments. Moreover, the factors driving outsourcing decisions are equally diverse, ranging from gaining flexibility and enhancing efficiency to reducing costs and avoiding fiscal or labor market regulations (Doellgast and Gospel, 2013).

In this context, the growth and expansion of facilities and multi-service companies is probably one of the most interesting developments in relation to outsourcing and its implications for industrial relations and employment. Outsourcing is far from being a new phenomenon, but only since the early 2000s has there been a significant expansion of FM companies in Europe, though uneven across countries. FM companies provide integrated services and the management of those services to other companies or facilities. Even though the integration and management components constitute the distinctive traits of this form of outsourcing, the reality is that FM firms very often compete as any other service company providing just one service to client companies. As a matter of fact, rather than competing in the integrated service providers market, FM companies often take advantage of the diversity of services provided to engage in cost competition, thus undermining the working conditions of some groups of workers through the application of lower standards in collective bargaining.

This paper analyzes collective bargaining in the FM sectors of six countries to explore the similarities and differences between them. The analysis serves to illustrate the differential impact of the national institutional setting in conjunction with the development of the FM sector on the protection enjoyed by FM workers through collective bargaining. It is, moreover, argued that the extension of the FM business model has not always adopted a highroad strategy enhancing the quality and efficiency through the integrated management and delivery of services. Rather, it has, in many cases, been a deliberate low-road strategy taking advantage of the multiple services provided and the opportunities offered by decentralization in collective bargaining to reduce costs and deteriorate employment conditions.

Section 1 of the paper discusses FM in light of the literature on the characteristics and impact of outsourcing and the specific characteristics of FM, including a typology of FM companies. Section 2 then discusses the methodology and the analytical strategy used. Section 3 shows the development of FM in the six countries compared. This is then followed by the analysis of FM actors and collective bargaining processes across the six countries.

\section{Outsourcing and facility management in the global value chain}

Most production and service provision processes are sequential and require establishing the so-called value chain, i.e. a relationship between the different processes required to produce a good or service (Huws and Podro, 2012; Antràs and Chor, 2013). The design of the economic value-added formula in the 1990s advocated that companies were more efficient when they removed as many items as possible from their balance sheets (Marchington et al., 2005). Outsourcing should accordingly be interpreted first and foremost as a business strategy with a financial/economic rationale. First, outsourcing is aimed at reducing costs in the short term 
(suppliers base their business on economies of scale, reusing models already developed for different clients). Second, it is also aimed at transforming companies' long-term cost structures by eliminating the fixed structures that support the internal control of the outsourced processes. Third, outsourcing constitutes a mechanism to enhance organizational flexibility, as it allows for a quicker adaptation to production requirements. Finally, the greater specialization of provider companies allows for efficiency gains (Kotlarsky et al., 2011; Doellgast and Gospel, 2013).

Since the 1980s, the modularization of tasks and processes in the value chain has been required to eliminate workers engaged in ancillary activities through outsourcing practices (Harrison and Kelley, 1993; Flecker and Meil, 2010). In turn, this allowed the organization of production around networks of supplier companies, increasingly favoring the market over organizations' internal competences (Ricart et al., 2011; Kirchner, 2015).

Through outsourcing, the delivery of non-core activities is extracted from the central organizations as well as the responsibility over labor and social issues of the workers completing these activities, thus dualizing workers' organizational and employment relations (Rivero et al., 2006; Doerflinger and Pulignano, 2015; Mori, 2015; Moreno et al., 2014). In this way, the reduction of labor-related risks and costs (including wages, absenteeism and conflicts, among others) mainly through vertical disintegration strategies is an important driver for outsourcing, which moves workers out of well-organized sectors and/or organizations to spaces with weaker structures of worker representation and lower capacity for collective action (Doellgast et al., 2009; Huws and Podro, 2012; Recio et al., 2015; Mori, 2015; Hyman, 2015; Benassi and Dorigatti, 2020). Therefore, client companies tend to trade the control of some internal work processes for low-pay strategies.

FM businesses appear to be opportunities for companies to compensate for this organizational fragmentation of work processes by integrating most of their outsourced activities in the same supplier firm. Therefore, FM allows simplification of interorganizational coordination and reduction of transaction costs; either FM firms provide the outsourced services or they procure services from external suppliers and manage the output from the service providers. Moreover, the management and delivery of these integrated outsourced services is increasing with the internationalization of contract procurement by multinationals, as FM companies sign contracts with large clients at the European level, facilitating standard processes with providers.

The literature on outsourcing has accordingly focused on the extension of decentralizing business strategies and their (negative) impact on employment conditions (Flecker and Meil, 2010; Flecker and Hermann, 2011; Batt and Nohara, 2009). More specifically, this literature assumes a universal adoption of these practices in labor-intensive activities. With notable exceptions (Doellgast et al., 2009; Geishecker et al., 2010, Grimshaw et al., 2015, Mori, 2017), the interaction between these strategies and industrial relations institutions and, more specifically, the role of collective bargaining, has been largely overlooked in comparative analyses. According to most works (Drahokoupil, 2015), certain activities will be, regardless of the country or the sector, outsourced. This article contributes to this literature and the theoretical debates accompanying the development of outsourcing by providing evidence on the ways whereby institutions mediate business strategies in relation to outsourcing.

\subsection{Defining facility management}

Defining the organizational boundaries of the FM business will help to understand the implications of this activity for employment relations and collective bargaining. However, the conceptual and empirical delimitation of FM poses several challenges, as it is a relatively new business strategy that spans traditional sectoral classifications and points to greater changes in relations between organizations, space and work (Grimshaw, 1999). Moreover, FM
Industrial relations in facility management

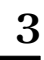


ER

44,7

4

companies adopt very different practices and strategies across countries, therefore making it even more difficult to define FM based on a set of common dimensions. Notwithstanding these problems, there is some consensus around the idea of an integrated management (and delivery) of non-core services and processes supporting the core business of an organization (Redlein, 2004; Ferri and Pala, 2009; Redlein and Zobl, 2014; IOS, 2017; Scholtens, 2017). What is accordingly distinct from other service providers is the integration and coordination of these ancillary activities. However, a relevant trend within FM managerial literature highlights that the coordination, rather than the provision of services, is the "bread and butter" of FM activity and notes its potential in contributing to wider business outcomes (Drion et al., 2012).

In light of the above, a distinction can be made between internal and external FM. As Figure 1 shows, FM activities (i.e. those tasks developed by professionals integrating and coordinating outsourced services) are not completely outsourced in the European market. A total of $49.5 \%$ of facility managers develop their activity internally (Global FM, 2018). Internal facility managers operate within client organizations while coordinating external supplier companies. By contrast, outsourced facility managers externally coordinate the integrated supply of outsourced services. These services can be delivered by the same company that coordinates externally or by other provider firms contracted by the FM company.

In terms of services provided, FM traditionally covered infrastructure and maintenance, equipment and furniture management, efficient resource supply, waste removal and security services. However, other functions, such as supervising environmental aspects or managing information technology (IT) systems, are increasingly common, especially in those countries with more developed FM. This wide range of activities supplied by FM companies explains the growth of FM in recent years and why it is becoming one of the largest business services markets in Europe (Global FM, 2016, 2018).

FM companies are generally classified according to their territorial scope (distinguishing companies that supply outsourced services to client organizations at the local, regional and global levels) but also in relation to the extent and complexity of activities supplied. In that sense, the literature distinguishes between multi-service suppliers, facility services suppliers and FM companies based on the number of activities covered and the level of integration and coordination between the services provided (Ferri and Pala, 2009; Hodge et al., 2014).

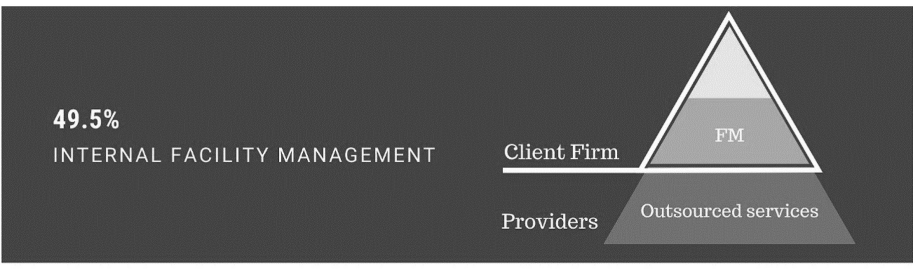

Figure 1.

Differences between internal and outsourced FM
Client Firm

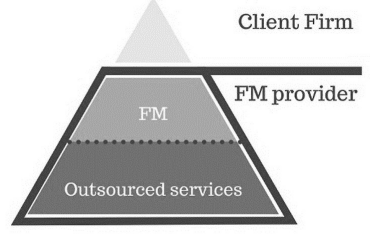

$50.5 \%$

OUTSOURCED FACILITY MANAGEMENT

Source(s): Own elaboration. Data related to Europe (Global FM 2018) 
Moreover, there are important differences across countries in relation to the development of the FM business and the type of services provided, allowing us to differentiate several market stages (Ferri and Pala, 2009; Teichmann, 2009): pre-emerging markets (mostly composed of single-service supply firms and client-supplier relationships based on multiple single-service and short-term contracts), emerging markets (with an incipient set of multiservice supply companies and a fragmentary supply concerning activities, territory coverage and clients, as well as a small number of multinationals with pan-European contracts), developed markets (where single-service supply co-exists beside multi-service supply, consolidating large supply operators) and advanced markets (with a large amount of integrated service supply and the implementation of public-private partnership projects) (Table 1).

The development of the FM business in a country has implications for the type of strategies followed. Thus, in pre-emerging/emerging markets, it is more likely to find FM companies follow a low road as they will tend to adopt price competition strategies vis-à-vis traditional service firms. While, in the advanced markets, it is more likely to find high-road strategies as FM companies have developed competitive strategies based on the integrated management and delivery of services. This usually requires higher skills, thus forcing these companies to follow non-price-competitive strategies.

\subsection{Facility management, labor market impact and industrial relations}

The services supplied by FM firms are generally labor-intensive and carried out by predominantly unskilled workers who are typically paid low wages (Price, 2015), and the rates of employment are higher for women and migrant workers. In that sense, an FM business gathers activities and workers frequently ascribed to the secondary segments of labor markets within the same organization, thus functioning as a parallel company of the client organizations supplying the ancillary activities. The question is accordingly whether FM contributes to maintaining the segmented pattern in the labor market or facilitates an upgrade in workers' positions.

The first "low-road" scenario relies on the capacity of this new business model to blur sectoral boundaries within the company and take advantage of this to develop cost-based competitive strategies, avoid collective bargaining regulations and maintain poor labor standards for some groups of workers. The adoption of this low road is facilitated by the low unionization rate of workers in FM activities and the spaces opened by the decentralization of collective bargaining (Cremers, 2009). By contrast, the "high-road" scenario goes hand-inhand with the capacity of the FM business model to manage services more efficiently through the improved inter-organizational coordination between clients and suppliers. This high-road strategy brings several benefits for client companies: clearer communication regarding

\begin{tabular}{llll}
\hline Pre-emerging markets & Emerging markets & Developed markets & Advanced markets \\
\hline Greece & Portugal & Austria & Denmark \\
Slovakia & Poland & Belgium & The Netherlands \\
Romania & Hungary & Luxemburg & UK \\
Estonia & Czech Republic & France & \\
Latvia & Slovenia & Germany & \\
Lithuania & Sweden & Ireland & \\
Cyprus & Finland & Italy & \\
Malta & Bulgaria & Spain &
\end{tabular}

Source(s): Own elaboration based on Ferri and Pala (2009) and Teichmann (2009)
Industrial relations in facility management 
ER

44,7

demand and supply, simplification of the internal and external responsibilities for services, reduction of conflict between the internal and external service providers, and improved synergy between services (Cigolini et al., 2009).

As pointed out in the previous section, the development of the FM activity is one element shaping the strategic orientation of the FM company. However, it is key to consider the role of industrial relations institutions (Grimshaw et al., 2015). Particularly important in this regard is the structure of collective bargaining referred to the relationship between the different levels (national, sectoral, company) where collective agreements are signed. Industrial relations and collective bargaining institutions could reduce the capacity FM companies have to use arbitrarily different sectoral or even company-level agreements as tools to put pressure on downgrading working conditions (Bondy, 2018). In this vein, collective bargaining coverage is an important dimension of industrial relations systems, as it determines the capacity of collective agreements to provide effective protection to workers. Moreover, it has also been identified as a key institution in reducing earnings disparities and limiting labor market dualization (Bosch, 2015). Thus, the existence of strong sectoral collective bargaining is an important element to ensure adequate collective bargaining coverage for the workers in FM companies. The coordinating role of sectors has, nonetheless, been weakened due to longrun decentralization dynamics (Traxler, 1995) and reforms introduced during the economic and financial crisis (Marginson, 2015). Likewise, the existence of strict and enforceable regulations in outsourcing, particularly in relation to the application of collective agreements to outsourced workers or in situations of transfer of undertakings, makes it more difficult for FM companies to follow the low road (Grimshaw et al., 2015).

Another important element to be considered is the role of trade unions and in particular, their capacity to organize and represent workers in outsourced services. Several studies have pointed out how outsourcing has led to a weakening of unions' capacity to effectively organize these workers (Holmes, 2004). Trade union efforts to adopt a proactive role at workplace level in response to outsourcing can have diverse effects depending on grassroot support from their members (Teicher et al., 2006), the institutional role of trade unions (Huws and Podro, 2012), the extension of collective bargaining coverage (GumbrellMcCormick, 2011) and the interplay between local and global workers representatives (Taylor and Bain, 2006), among other factors. Although diminishing, internal coordination between different worker representatives through coordinated bargaining between unions and works councils is still key to reinforce union strength in face of outsourcing strategies (Doellgast, 2009).

Furthermore, coordination mechanisms can intervene in buffering market challenges and minimizing inequalities between workers of internal and outsourced services, such as pay adjustment schemes, the application of Transfer of Undertakings-Protection of Employment (TUPE) legislation and the use of information and consultation mechanisms at workplace level (Mori, 2017). Also, the room of maneuver to include social clauses in procurement processes covering pay and employment conditions can both reduce the risk of outsourcing of public services (Grimshaw et al., 2015) and increase the protection of outsourced workers (Mori, 2017).

\section{Methodology and analytical strategy}

This paper analyzes collective bargaining in the FM activities of six countries to explore the similarities and differences between them and shed light on the following questions: what is the role of industrial relations institutions in shaping the strategies of FM companies? More specifically, how does collective bargaining ensure the adequate coverage of FM workers across countries with different industrial relations institutions and levels of development of the FM sector? 
The analysis was carried out for an FM multinational company providing services in six European countries (France, Italy, The Netherlands, Poland, Spain and the UK). Taking into consideration the classification by Ferri and Pala (2009) and Teichmann (2009) (Table 1), the six countries studied represent most of the market stages in the FM business, showing the first steps of the FM market (Poland), its business maturity (France, Italy and Spain) and its consolidation (The Netherlands and the UK). The general trend within developed and advanced markets is the consolidation of integrated services delivery within the same business group (facility services) coexisting with its management by the same company (FM).

Moreover, the six countries cover most of the types of industrial relations systems in Europe whether we use national models (Visser, 2009) relying on the typologies of national production and employment regimes; sectoral composition models (Bechter et al., 2012), which reduce the importance of the national IR setting to pay more attention to the increasing global coordination of sectors; or typologies that adopt a broader scope (Eurofound, 2018), including not only the main actors, institutions and processes but also their impacts on relevant socioeconomic fields such as equity and efficiency. This article considers the contributions of this debate, incorporating the three typologies to understand the various cases in relation to the national model, the sectoral composition and the socioeconomic outputs, and provides a better understanding of the implications for FM workers.

According to these typologies (Table 2), Italy, France and Spain are generally categorized under the same system, which entails high collective bargaining coverage within relatively centralized collective bargaining institutions and where the state plays an important role in regulating and coordinating employment relations (Molina, 2014; Eurofound, 2018, p. 39). In this group of countries, sectoral agreements play a strong role and extensions are widely used (OECD, 2017; Garnero, 2020). The social partnership model of The Netherlands is characterized by centralized collective bargaining, a high degree of coordination, high collective bargaining coverage rates and the institutionalized involvement of social partners in policymaking (Eurofound, 2018, p. 37). In this model, sectoral collective bargaining also plays a key role, but they also leave significant room for lower level agreements to set standards, either by limiting extensions or allowing opt-outs from sectoral collective agreements (OECD, 2017; Garnero, 2020). Finally, Poland and the UK, though belonging to different systems (Liberal and Centre-East, respectively, see Visser, 2009), share some common features (Bechter et al., 2012, p. 198). In fact, Eurofound (2018) classifies both countries within the same IR model defined by the weakness of social partners, the minor role played by the state in industrial relations, the low level of bargaining coverage and the uncoordinated and decentralized nature of the collective bargaining (Eurofound, 2018, p. 40; OECD, 2017; Garnero, 2020).

\begin{tabular}{|c|c|c|c|}
\hline & Visser (2009) & $\begin{array}{l}\text { Bechter et al. } \\
(2012)\end{array}$ & Eurofound (2018) \\
\hline $\begin{array}{l}\text { Italy } \\
\text { France } \\
\text { Spain }\end{array}$ & South (polarized pluralism) & State-centered & $\begin{array}{l}\text { State-centered associational } \\
\text { governance }\end{array}$ \\
\hline $\begin{array}{l}\text { The } \\
\text { Netherlands }\end{array}$ & $\begin{array}{l}\text { Center-West (social } \\
\text { partnership) }\end{array}$ & Social partnership & Social partnership \\
\hline Poland & $\begin{array}{l}\text { Center-east (transition } \\
\text { economies) }\end{array}$ & Mixed & Market-oriented governance \\
\hline UK & West (liberal pluralist) & Liberal & \\
\hline
\end{tabular}

Source(s): Own elaboration
Industrial relations in facility management 
ER

44,7

8

The structure of the representation of FM actors at the European and national levels reflects the relatively recent and differentiated development FM has had across the European Union (EU) countries. At the European level, the European Facility Management Network (EuroFM) and International Facility Management Association - Europe (IFMA Europe) are the largest business associations for FM activity. EuroFM also works as a professional association representing individual facility managers. There are no employer organizations at the European level representing the interests of national-level organizations and participating in European social dialogue. Regarding workers' representation, employees engaging in FM activities are represented in the European Trade Union Confederation (ETUC) through its sectoral federations and through European works councils (EWCs) in cases where FM multinational firms are present in several EU member states. That is the case of some of the largest FM multinationals operating in Europe: Aramark, Compass Group, Integrated Service Solutions (ISS), Johnson Controls International and Sodexo all have EWCs, though the activities and role of EWCs differ significantly across them (Aramark only had one agreement in 1996, while ISS bargained for one original agreement in 1996 and four renegotiations between 1998 and 2013). Other large FM multinationals have not developed any social dialogue through EWCs: CBRE Group, Cushman and Wakefield, Dussmann Group and Jones Lang Lasalle Incorporated (The European Works Councils database, 2020).

In each country analyzed, semi-structured interviews were carried out with the sectoral trade union representatives (seven), the employer organization managers (three), the FM multinational workers' committee members (seven), the FM company's national human resources or management departments (nine), the multinational's European works council members (one) and experts in IR and FM (four). The interviews were carried out following a standardized questionnaire adapted to the national conditions. Moreover, the FM multinational analysis adopted a case study methodology, focusing on empirical and general cases (Ragin and Becker, 1992; Byrne and Ragin, 2009) of industrial relations practices in a business organization. Several sources of information were used to implement the case study analysis, triangulating interview data with internal data provided, documentary sources from publicly available company and national reports to validate our findings.

\section{Playing under different rules: collective bargaining and industrial relations in facility management}

As a business model, FM cuts across traditional sector-based boundaries in industrial relations. The "chameleonic" character of FM companies provides them an advantageous position in relation to traditional firms/competitors. However, the opportunities and incentives to follow a low-road competition critically depend on the interaction between the development of FM activities and the institutional setting. It is, therefore, important to understand under which conditions the extension of the FM model in a country has facilitated the adoption of a low- or a high-road strategy. These conditions are related to the national systems of collective bargaining, the mechanisms of extension and coordination of agreements, the inclusion of certain social clauses and the strategies deployed by employers and trade unions (mostly based on organizational and institutional resources).

To address this question, we analyzed the role of an FM multinational company operating in the six European countries identified above. This will shed light on the importance of the institutional setting in shaping national practices/strategies. Multiserv [1] is a multinational firm with a history of more than 100 years and with a presence in Europe, Asia, America and Australia. Originally, it was a cleaning company that underwent an important international expansion during the 1990 and 2000s. Currently, Multiserv provides a wide range of services in 50 countries and has more than 530,000 employees. In Europe, Multiserv's presence is more 
important in the UK $(43,000)$, Spain $(30,000)$ and France $(22,000)$ and has smaller workforces in The Netherlands $(6,500)$, Poland $(2,100)$ and Italy $(762)$.

Multiserv began its operations in all six countries in the highly cost-competitive cleaning sector, where short-term contracts and low wages were common. However, it gradually shifted toward the FM sector and currently provides a wide range of services beyond cleaning: catering, security, housekeeping, reception, maintenance, mailroom, information and communication technology (ICT), etc. Multiserv provides and manages all the general services that a facility or company may require. The strategy of the company is to offer these services in an integrated way to its clients by not just supplying these services but also coordinating them with the core activities of the client organizations through the implementation of standard business processes at the global level. According to Multiserv, knowledge about different sectoral principles is key to provide tailored solutions to its clients' needs. This strategy has led to the acquisition of national companies in all the countries analyzed and has allowed Multiserv to expand the activities and areas it covers while accessing new markets.

Employees in Multiserv consist of a large number of women (57-80\%, depending on the country, reflecting the feminization of the main activity of the company: cleaning) and a high rate of migrant workers (e.g. $70 \%$ in Italy). Open-ended contracts are predominant (e.g. $95 \%$ in Spain) because of the limitations imposed by the Transfer of Undertakings regulation at the national level. However, job turnover is high, especially in the case of cleaning personnel. In addition, career development prospects or training activities are rather limited. Approximately $60-80 \%$ of the workforce have part-time contracts, which are particularly frequent among women and in some cases can be for as low as $10 \mathrm{~h}$ a week. Notwithstanding the predominance of open-ended contracts, the company frequently uses overtime work as a form of quantitative adjustment. The services provided by the company are predominantly low skilled and very often low pay: wages fluctuate between the minimum wage established in each country and $20 \%$ above the minimum wage. Even though Multiserv claims that it would like to pay better wages, the strong competition in the FM market constitutes a major obstacle.

The evidence collected shows that Multiserv is a better employer in general terms compared to other FM companies in the countries included in the analysis. In this way, Multiserv tends to set working conditions above statutory minima. Therefore, the low quality of employment conditions described above seems to be inherent to employment in the bottom of the labor market, of which FM activities are a part. Nevertheless, this environment does not totally determine a company's strategy. As Multiserv's case clearly shows, companies retain some capacity to adopt a different approach leading to better employment conditions. This can increase job quality and upward mobility instead of leading FM workers toward bundles of low-wage tasks.

\subsection{Industrial relations actors and strategies in the facility management business}

The organization and representation of FM companies are complex due to the wide range of activities covered by the FM business, which does not easily fit into the predominantly sectoral organization of industrial relations actors and collective bargaining. The representation structures of workers and employers' organizations are rooted in sectoral principles of federations and associations linked to the development of a specific economic activity. Mergers in trade union structures have somewhat eased these problems of intersectoral coordination for FM companies.

The analysis of the actors representing FM firms or their workers across the six countries and their industrial relations strategies deployed reveal a picture that varies along with the diversity of stages in FM development in the country and industrial relations models (Figures 2 and 3$)$.
Industrial relations in facility management 
ER

44,7

10

Figure 2.

Employers'

representation in the FM business

Figure 3.

Collective bargaining processes in the FM business
NONSPECFIC ACTORS

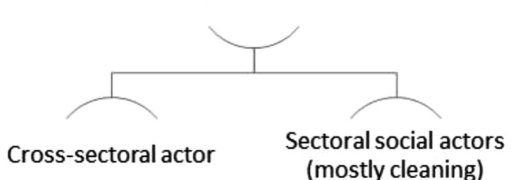

(mostly cleaning)
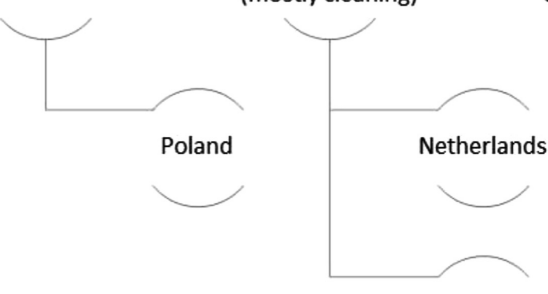

Italy

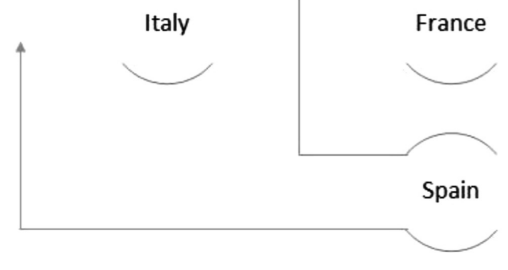

Source(s): Own elaboration
FM ORGANIZATIONS

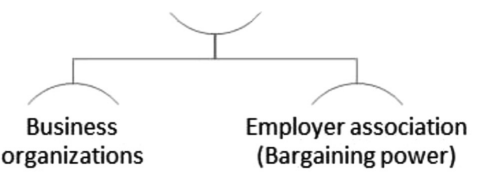

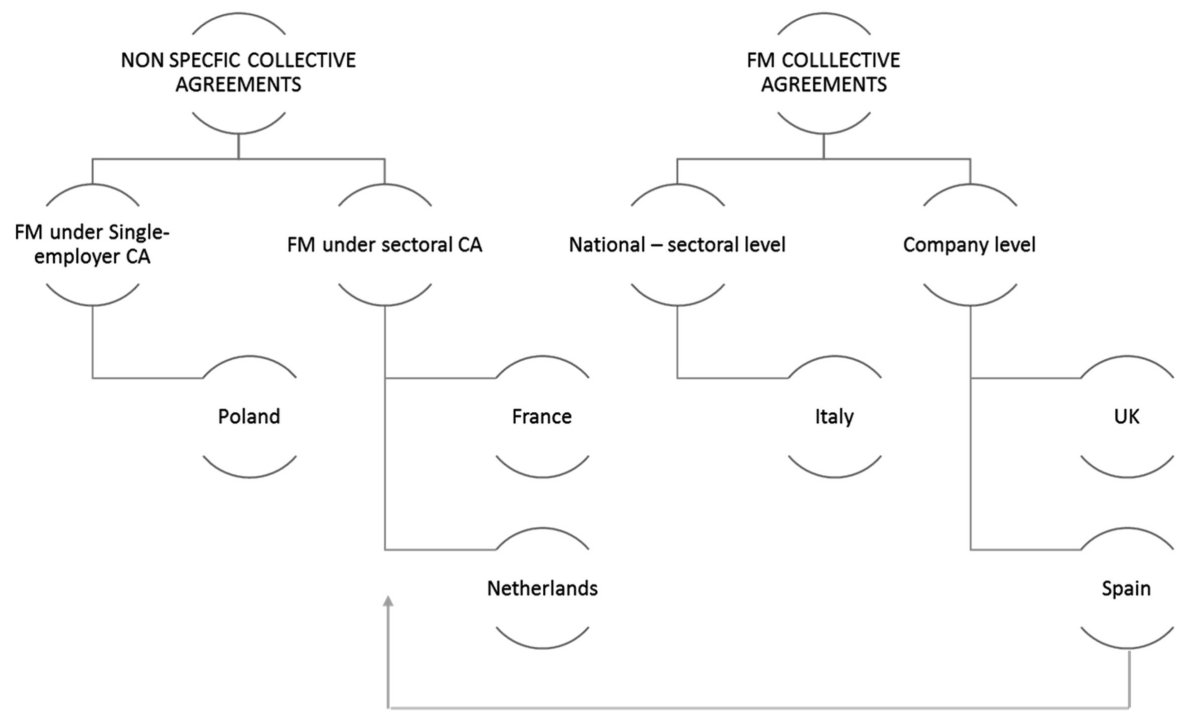

Source(s): Own elaboration

4.1.1 Netherlands and the UK; advanced FM markets in most different institutional frameworks. The advanced FM market of The Netherlands is dominated by a few large companies. The five largest FM companies are members of one or more employer organizations in the cleaning, contract catering and security sectors, which negotiate their 
sectoral collective agreements. According to the Dutch branch of Multiserv, these sectoral collective agreements prevent downward wage competition, although a number of companies do not respect the appropriate application of these agreements. These sectoral employer organizations cooperate establishing a common institutional position for a so-called service pact to protect employment in facility services. For example, by preventing public administrations unfair competition. Dutch employer organizations have elaborated a code of good practices in tendering emphasizing service quality and social responsibility over price considerations. The Dutch branch of Multiserv is one of the leading companies on these institutional and internal regulatory practices. Moreover, Dutch trade union representatives have established together with employers (including Multiserv) periodical revisions of coverage problems related to workers who fall under the cleaning agreement but perform other activities not under the scope of this sectoral agreement. Dutch unions have, therefore, reinforced institutional resources as a mechanism to protect employees. Thus, in the Dutch case, sectoral collective bargaining pre-empts low wage competition. This is reinforced by other mechanisms such as codes of good practices in tendering. Under these conditions, FM companies have developed competitive strategies based on integrated service provision.

In the case of the also mature FM market of the UK, dominated by a number of large multinationals, companies count with encompassing trade associations carrying out lobbying and advisory activities, but not involved in collective bargaining processes. Negotiations take place predominantly at company level in the FM business. Multiserv is predominantly known in the UK in having a management approaching more to the importance of non-conflict-oriented employee relations in contrast to other FM firms (according to employer and union representatives). In that regard, the company tends to focus on quality rather than cost reduction strategies wherever possible in contrast of general practices of FM companies in the UK. In that regard, the main difficulties of unions to bargain were more related to the lack of experience of local managers, who are under time pressure and unused to dealing with trade unions. That is why, union representatives collaborate with Multiserv through training programs for all these local management staff to instruct them on collective bargaining issues. The UK case shows how in an advanced FM market, where the institutional setting makes in principle feasible to follow low-road competitive strategies, companies might find it rational/advantageous to exploit integrated delivery and quality approach.

4.1.2 Developed facility management markets meet strong industrial relations institutions in France, Italy and Spain. Italian FM companies are represented through sectoral federations affiliated with the major employer organizations operating in the cleaning industry sector, where a section of multi-service industry exists. The gradual transformation of large cleaning companies into FM multinationals explains this organizational structure that has been reinforced by the existence of a specific collective agreement for facility services replacing the sectoral negotiation of the industrial cleaning industry. This sectoral FM agreement has become a key instrument for the regulation of Italian FM companies; in some cases, because of its extension or simply becoming a pattern for company-level agreements. Besides the active role of employer organizations promoting this agreement, largest trade unions agreed on the benefits of a comprehensive regulation of the FM business.

Multiserv adhered to this collective agreement, thanks to its wide scope in terms of activities and occupations covered. However, trade unions consider that as far as the company provides an increasing number of services, coverage problems may rise. Moreover, trade unions also criticize the fact that Multiserv is subcontracting some of its activities to other companies (70\% according to trade unions). As some of these subcontractors apply collective agreements signed by poorly representative employer and workers' organizations, trade unions claim that subcontracting has become an instrument to indirectly erode working conditions and reduce costs. Another mechanism criticized by trade unions is the dualization
Industrial relations in facility management 
ER

44,7

of working conditions between workers in headquarters and the rest of employees. This dualization results from the application of a company-level agreement with better working standards to the headquarters workforce, different from the agreement to most of its workforce. Unions managed to extend these conditions to workers providing services in maintenance, internal logistics and mail handling services outsourced in some banks and universities.

The Italian case shows the mutual benefits for employers and trade unions of having a specific FM collective agreement. This agreement serves to prevent downward competition, but also to ensure common conditions for workers in the FM company, irrespectively of the sector/service. But, it is also important to consider the role of strong local union branches in enforcing the agreement and ensuring compliance with its terms and conditions.

In France, there are three FM trade associations (aka business associations) with most of the firms and many of the managers within their members. However, FM companies are represented in collective negotiations by the employer organizations linked to the activities they carry out (cleaning, security, etc.) (Figure 2). As a consequence, different sectoral collective agreements in these activities are applied to workers in FM companies, depending on the type activities/services they perform, thus allowing different employment conditions. French unions highlight the effectiveness of these institutional mechanisms for the adequate protection of workers, but they also admit differences in coverage and compliance across sectors. Unions have accordingly demanded strict compliance with sectoral collective agreement according to the activity of the client company, instead of the CB of the activity developed for cleaners in railway services and chambermaids in hotels.

In the case of Multiserv, trade unions have attacked some practices, including the application of sectoral collective agreements setting lower standards (e.g. cleaning) to workers performing logistic activities. As French FM companies face increasingly pressure from clients to reduce costs, sectoral collective agreements provide a safety net to avoid downward spiral of cost competition within the FM business. Moreover, trade unions have also denounced other practices, including dismissals following cases of transfer of undertakings with imbalances between the cost demanded by client organizations and the labor cost of former workers that become Multiserv employees. The company generally applies internal flexibility measures (reorganization of workers, reduction of working hours, etc.), but also dismissals as mechanisms of adjustment. Unions mobilized their members to call demonstrations and strikes. These actions have raised awareness enough to make some client organizations to finish business relations with Multiserv.

The existence of a specific FM collective agreement in Italy compared to the application of different sectoral collective agreements in France, constitutes a guarantee. The maintenance of separated sectoral collective agreements in France opens the door for FM companies to take advantage of differences in employment standards to reduce labor costs.

Spain has in recent years experienced an extension of FM business, becoming a developed FM market, following a similar process to that depicted in Italy. However, contrary to the Italian case, Spain has not yet a specific FM sectoral collective agreement. The collective bargaining framework in Spain is characterized by the importance of sectoral collective agreements. Sectoral coordination of collective bargaining prevailed until the 2012 labor law reform opened the door to a decentralization of collective bargaining through the extension of opting out clauses in company-level agreements. This allowed FM companies to prefer company-level agreements to set lower standards than sectoral agreements. Moreover, lacking a specific sectoral collective agreement, FM companies could pick up the sectoral collective agreement related to the many services they deliver, more convenient to their interests, usually the one for the industrial cleaning sector, as this is the one setting lower standards. Trade unions responded to these challenges first by appealing to justice. Second, gradually introducing clauses aimed to solve the problem of indeterminacy of the collective 
agreement to be applied to FM workers (Figure 3) while discouraging the arbitrary application of collective agreements in the FM business. Meanwhile, some of the largest FM employers had contacts to launch their own employer organization to promote sectoral negotiations for the FM businesses. According to employers, having a specific sectoral collective agreement would allow all workers in FM companies to enjoy similar conditions. However, trade unions interpreted this move as a further attempt at eroding employment conditions. This proposal was finally dismissed due to unfruitful negotiations with unions and the multiple judgments canceling FM company agreements.

Multiserv was, however, not involved in these practices to organize CB specific for the FM business neither negotiating its own company-level agreement to lower employment standards. As a matter of fact, trade unions report Multiserv as a case of best HR and employment relations practices in Spain's FM business. However, similarly to its Italian branch, Multiserv applies a collective agreement to its headquarters workers (above sectoral standards), causing similar demands by unions to extend its coverage for the whole company.

4.1.3 Poland: an emerging facility management market in a weak institutional setting. Poland is the only case of emerging FM market among all the studied here. The lack of specific FM employer organizations responds to the lack of multi-employer (sectoral) collective bargaining in its industrial relations system, including the FM business or any of the activities performed by these companies. Working conditions depend mostly on the terms agreed between the company and client organizations than any standardized collective bargaining process as these business relations include employment standards on wages, working hours and type of contracts (permanent, fixed-term, self-employment, etc.), among other employment issues.

Therefore, working conditions vary depending on each client organization. However, interviewees confirm that most of agreements signed by Multiserv entail employment contracts covered by social protection. That is full social contributions and labor rights such as holidays, working time regulations, minimum wages and collective rights. That contrasts the frequent atypical forms of employment in other FM companies in Poland, resulted from the application of civil law contracts, which offer a lower standard of social protection (only partially covered by social contributions, no regulations on working time nor leave or holidays and without specific collective rights). There are not particular initiatives of Polish unions in regard of problems of coverage of Multiserv workers, in spite of the application of civil law contracts to a (minor) part of its workforce.

\subsection{Analysis and assessment}

The wide range of services provided by FM companies make it impossible to identify them under a single sector and opens the door to opportunistic behavior. More specifically, as collective bargaining in most EU countries is structured along sectoral lines, it is often difficult to know what collective agreement and, by implication, wages and working conditions should apply to the FM companies' workers. Different institutional settings, however, interact with different stages in the development of the FM business in shaping the strategies FM follow.

In countries with weak industrial relations institutions, decentralized collective bargaining systems and limited coverage of collective agreements, Multiserv has more incentives to follow the low road and adopt a low-wage competitive strategy irrespectively of the degree of development of the FM business. Thus, in the UK, where there is no specific sectoral collective bargaining in FM nor in the sectors that carry out the FM activities, collective bargaining coverage only exists for those Multiserv workers in client companies having their own collective agreement. As a result, we find significant differences among Multiserv workers in relation to working conditions, even when they carry out similar

Industrial relations in facility management 
ER

44,7

functions. A similar situation has been observed in Poland a country with a less advanced FM business. Here, company-level agreements are even less common than in the UK, thus leading to a situation characterized by the predominance of individual negotiations and employment standards depending exclusively on negotiations between clients and employers, which place workers in a very weak position. This explains why in Poland, FM employees receive low wages, experience high levels of job insecurity and rotation, and endure common and arbitrary inequality. However, the management approach is relevant ensuring more protection to Polish and British Multiserv employees in comparison to FM national averages.

The situation is very different in countries with collective bargaining systems where sectoral collective bargaining is widespread. In the mature FM sector of The Netherlands and the advanced FM business systems of France, Italy and Spain, strong collective bargaining institutions set some boundaries to the strategies of FM companies. However, the existence of specific FM collective agreements constitutes an important difference within this group. In France, The Netherlands and Spain, FM workers are covered by cleaning, maintenance, environmental management, security and other facility services sectoral collective agreements. Even though collective bargaining coverage is high in both cases, this introduces a fragmentation in working conditions across workers within FM companies. By contrast, the cleaning and multi-services sectoral agreement in Italy protects most of the FM employees while contributing to set similar employment standards. However, the existence of companylevel collective agreements for Multiserv in some countries serves to protect its administrative and management staff while ensuring protection for the workers not covered by sectoral collective agreements. That is the case for Multiserv in The Netherlands and Spain, and it has a direct impact on the prevailing working conditions, including wages that are above the minimum wage, greater job security and career advancement and training opportunities. Moreover, some of these sectoral- and company-level agreements include mechanisms limiting short-term contracts and workload, allowing additional protection for some Multiserv employees. However, in The Netherlands and especially Spain, the common scenario is that the FM company applies many different sectoral agreements and deals with the uncertainty of situations in which employees are engaged in more than one activity. However, the company generally prefers this situation since it brings them certainty regarding which agreement to apply, although it complicates the job of the worker representatives. In relation to these diverse coverage situations, the Dutch Multiserv branch is in favor of implementing a single company agreement for all activities developed by the firm.

By contrast, the company's Spanish management is explicitly against implementing any company agreement (considering that in the Spanish context, it means working conditions will worsen), but they may be interested in a sectoral agreement to cover ancillary services. However, the boundaries are not clear, and moreover, there are too few companies for a sectoral agreement. Finally, in Italy, where a sectoral collective agreement for cleaning and multi-service companies exists, most workers in Multiserv are covered by the agreement. Those Multiserv workers not covered by this agreement are, however, under the sectoral collective agreement of their activities, thus guaranteeing high levels of coverage and protection.

\section{Conclusions}

The objective of this article was to explore the interaction between industrial relations institutions and the type of FM markets in shaping companies' strategies and the impact on employment standards. More specifically, the analysis of an FM multinational operating in six countries serves to illustrate the differential impact of domestic institutions in shaping the protection of collective agreements to these workers. As a form of outsourcing, FM companies offer a wide range of services and the integrated management of those services to their client 
companies. Similar to other forms of outsourcing, FM might lead to further fragmentation of employment relations: it complicates the organization and representation of the workers, crosses sectoral boundaries and makes the application of collective agreements more uncertain. By contrast, the concentration of outsourced workers under the same supplier organization introduces a distinctive element that can also facilitate the adoption of mechanisms to ensure the protection of workers and improve their positions.

The analysis first reveals marked differences across countries in the ways FM companies are represented and engage in collective bargaining. These differences do not correspond to the stages of development of the FM business, therefore highlighting the role of the institutional setting in shaping the strategies of FM companies and their role in collective bargaining. The chameleonic character of FM companies' reliance on the wide range of services they provide has allowed them to easily adapt to different domestic institutional environments and find the best way to compete with other service providers. Second, the results also show the importance of strong sectoral collective bargaining institutions to protect workers in outsourced services, including those in FM companies. However, the effectiveness of multi-employer collective bargaining in avoiding a race to the bottom and wage competition has been undermined in some countries as a result of decentralization. This has allowed FM companies to sign collective agreements that opt out of the conditions established at the sectoral levels and set lower standards for all their workers, irrespective of the activity performed or their skill level.

The paper also contains important policy insights. More specifically, it is showed that moving from a cost-competition strategy toward a high-quality road in the FM industry requires combining several elements and policies. First, it requires a stronger managerial focus on the integrated coordination of services. This would contribute to increasing the value added by the services provided by FM companies, hence contributing to shifting the view of those services from costs to resources. Second, ensuring the predominance of sectoral collective bargaining would also help to set limits on wage-undercutting strategies. Another element contributing to reaching this goal is the implementation of national and EU regulations on tendering, public procurement and codes of conduct.

Finally, the paper provides relevant theoretical insights to the industrial relations field. In particular, by combining the extant literatures on multinationals and outsourcing, it shows the crucial role of national institutions in mediating the effects of outsourcing strategies by multinational companies. Based on comparative evidence from a multinational company in the FM business, the paper shows adaptation to the domestic institutional framework, and more specifically, to the collective bargaining system and the boundaries it poses for outsourcing. Notwithstanding the erosion experienced by industrial relations during the Great Recession, the evidence shows how collective bargaining institutions still play a crucial regulatory role, in this case by shaping outsourcing practices and its impact on working conditions.

\section{Note}

1. Multiserv is a fictional name used to preserve the anonymity and confidentiality of the key informants interviewed and to emphasize that the company itself is not important, but rather its context and practices.

\section{References}

Antràs, P. and Chor, D. (2013), "Organizing global value chain”, Econometrica, Vol. 81 No. 6, pp. 2127-2204.

Batt, R. and Nohara, H. (2009), "How institutions and business strategies affect wages: a cross-national study of call centers", ILR Review, Vol. 62 No. 4, pp. 533-552.

Industrial relations in facility management 
ER

44,7

16

Bechter, B., Brandl, B. and Meardi, G. (2012), "Sectors or countries? Typologies and levels of analysis in comparative industrial relations", European Journal of Industrial Relations, Vol. 18 No. 3, pp. $185-202$.

Benassi, C. and Dorigatti, L. (2020), "Out of sight, out of mind: the challenge of external work arrangements for industrial manufacturing unions in Germany and Italy", Work, Employment and Society, Vol. 34 No. 6, pp. 1027-1044, doi: 10.1177/0950017020903039.

Bondy, A. (2018), "The (dis) advantages of sector-level bargaining: outsourcing of cleaning work and the segmentation of the Israeli industrial relations system", Journal of Industrial Relations, Vol. 60 No. 5, pp. 691-710.

Bosch, G. (2015), "Shrinking collective bargaining coverage, increasing income inequality: a comparison of five EU countries", International Labour Review, Vol. 154 No. 1, pp. 57-66.

Byrne, D. and Ragin, C. (2009), The Sage Handbook of Case-Based Methods, Sage Publications, London.

Cigolini, R.D., Van der Zwan, J., Straub, A., Martinez, D., Aiello, G., Mazziotta, V. and Micale, R. (2009), "Facility management, outsourcing and contracting overview", in Cigolini, Deshmukh, Fedele and McComb (Eds), Recent Advances in Maintenance and Infrastructure Management, Springer, London, pp. 225-290.

Cremers, J. (2009), "Changing employment patterns and collective bargaining: the case of construction", International Journal of Labour Research, Vol. 1 No. 2, pp. 201-217.

Doellgast, V. (2009), "Still a coordinated model? Market liberalization and the transformation of employment relations in the German telecommunications industry", Industrial and Labor Relations Review, Vol. 63 No. 1, pp. 3-23.

Doellgast, V. and Gospel, H. (2013), "Outsourcing and human resource management [Electronic version]", Retrieved from Cornell University, ILR School site, available at: http:// digitalcommons.ilr.cornell.edu/articles/1217 (accessed 15 September 2020).

Doellgast, V., Holtgrewe, U. and Deery, S. (2009), "The effects of national institutions and collective bargaining arrangements on job quality in front-line service workplaces", Industrial and Labor Relations Review, Vol. 62 No. 4, pp. 489-509.

Doerflinger, N. and Pulignano, V. (2015), "Outsourcing and collective bargaining in the recent crisis: implications for employment in multinationals", in Drahokoupil, J. (Ed.), The Outsourcing Challenge. Organizing Workers across Fragmented Production Networks, ETUI, Brussels.

Drahokoupil, J. (Ed.) (2015), The Outsourcing Challenge: Organizing Workers across Fragmented Production Networks, ETUI.

Drion, B., Melissen, F. and Wood, R. (2012), "Facilities management: lost, or regained?", Facilities, Vol. 30 Nos 5/6, pp. 254-261.

Eurofound (2018), Measuring Varieties of Industrial Relations in Europe: A Quantitative Analysis, Publications Office of the European Union, Luxembourg.

EWCDB (2020), "The European works councils database", available at: http://www.ewcdb.eu (accessed 30 September 2020).

Ferri, A. and Pala, F. (2009), "The facility management market in Europe and Italy", in De Toni, A. Ferri, A. and Montagner, M. (Eds), Open Facility Management. A Successful Implementation in a Public Administration, IFMA, Milan, pp. 3-28.

Flecker, J. and Hermann, C. (2011), "The liberalization of public services: company reactions and consequences for employment and working conditions", Economic and Industrial Democracy, Vol. 32 No. 3, pp. 523-544.

Flecker, J. and Meil, P. (2010), "Organisational restructuring and emerging service value chains: implications for work and employment", Work, Employment and Society, Vol. 24 No. 4, pp. 680-698. 
Garnero, A. (2020), "The impact of collective bargaining on employment and wage inequality: evidence from a new taxonomy of bargaining systems", European Journal of Industrial Relations, Vol. 27 No. 2, pp. 185-202.

Geishecker, I., Görg, H. and Munch, J.R. (2010), "Do labour market institutions matter? Micro-level wage effects of international outsourcing in three European countries", Review of World Economics, Vol. 146 No. 1, pp. 179-198.

Global FM (2016), "Global FM market report 2016”, available at: https://www.efsme.com/newsroom/ wp-content/uploads/2018/11/Global-FM-Market-Sizing-Study-2016.pdf (accessed 11 November 2020).

Global FM (2018), "Global FM market report 2018”, available at: https://www.hanze.nl/assets/instituutvoor-facility-management/Documents/Public/24315\%20Global $\% 20 \mathrm{FM} \% 20$ Market $\%$ 20Report \%202017_0\%20\%28002\%29.pdf (accessed 11 November 2020).

Grimshaw, B. (1999), "Facilities management: the wider implications of managing change", Facilities, Vol. 17 Nos 1/2, pp. 24-30.

Grimshaw, B., Rubery, J., Anxo, D., Bacache-Beauvallet, M., Neumann, L. and Weinkopf, C. (2015), "Outsourcing of public services in Europe and segmentation effects: the influence of labour market factors", European Journal of Industrial Relations, Vol. 21 No. 4, pp. 295-313.

Gumbrell-McCormick, R. (2011), "European trade unions and 'atypical' workers”, Industrial Relations Journal, Vol. 42 No. 3, pp. 293-310.

Harrison, B. and Kelley, M.R. (1993), "Outsourcing and the search for Flexibility”, Work Employment and Society, Vol. 7 No. 2, pp. 213-235.

Hodge, G., Poglitsch, R. and Ankerstjerne, P. (2014), Perspectives on the FM Market Development, ISS, White Paper, available at: http://www.publications.issworld.com/ISS/External/issworld/White_ papers/Perspectives_on_the_FM_market_development/?page =1 (accessed 10 September 2018).

Holmes, J. (2004), "Re-scaling collective bargaining: union responses to restructuring in the North American auto industry”, Geoforum, Vol. 35 No. 1, pp. 9-21.

Huws, U. and Podro, S. (2012), "Outsourcing and the fragmentation of employment relations: the challenges ahead", Acas - Future of Workplace Relations discussion paper series, No. 1.

Hyman, R. (2015), “Three scenarios for industrial relations in Europe”, International Labour Review, Vol. 154 No. 1, pp. 5-14.

IOS (2017), "Definition 41011:2017", available at: https://www.iso.org/standard/68167.html (accessed 29 August 2018).

Kirchner, S. (2015), "Who performs outsourcing? A cross-national comparison of companies in the EU-28", in Drahokoupil, J. (Ed.), The Outsourcing Challenge. Organizing Workers across Fragmented Production Networks, ETUI, Brussels.

Kotlarsky, J., Oshri, I. and Willcocks, L.P. (2011), The Handbook of Global Outsourcing and Offshoring, Palgrave Macmillan, New York.

Marchington, M.P., Grimshaw, D., Rubery, J. and Willmott, H. (2005), Fragmenting Work: Blurring Organisational Boundaries and Disordering Hierarchies, Oxford University Press, Oxford.

Marginson, P. (2015), "Coordinated bargaining in Europe: from incremental corrosion to frontal assault?", European Journal of Industrial Relations, Vol. 21 No. 2, pp. 97-114.

Molina, O. (2014), "Self-regulation and the state in industrial relations in Southern Europe: back to the future?”, European Journal of Industrial Relations, Vol. 20 No. 1, pp. 21-36.

Moreno-Colom, S., Godino, A. and Recio, A. (2014), "Servicios externalizados y condiciones laborales: de la competencia de precios a la presión de los tiempos de trabajo", Sociología del Trabajo, Vol. 81, pp. 50-67.

Mori, A. (2015), "Outsourcing public services: local government in Italy, England and Denmark", in Drahokoupil, J. (Ed.), The Outsourcing Challenge. Organizing Workers across Fragmented Production Networks, ETUI, Brussels.
Industrial relations in facility

management 
ER

44,7

Mori, A. (2017), "The impact of public services outsourcing on work and employment conditions in different national regimes", European Journal of Industrial Relations, Vol. 23 No. 4, pp. 347-364.

OECD (2017), "Collective bargaining in a changing world of work", OECD Employment Outlook 2017, OECD, Paris, pp. 125-186.

Price, I. (2015), People Make, and Patterns Break, FM, EuroFM, Research Papers 2015.

Ragin, C. and Becker, H. (1992), What Is a Case?, Cambridge University Press, New York.

Recio, A., Moreno-Colom, S. and Godino, A. (2015), "Out of sight: dimensions of working time in gendered occupations", Hard Work in New Jobs (189-207), Palgrave Macmillan, London.

Redlein, A. (2004), Facility Management: Business Process Integration, Diplomica Verlag.

Redlein, A. and Zobl, M. (2014), "Outsourcing: a cost-saving approach in FM?", Proceedings CIB Facilities Management Conference, pp. 21-23.

Ricart, J.E., Agnese, P., Pisani, N. and Adegbesan, T. (2011), Offshoring in the Global Economy: Management Practices and Welfare Implications, Fundación BBVA, Bilbao.

Rivero, J., de Val, A.L. and de Val, J.J. (2006), La negociación colectiva en el sector de empresas multiservicios, Ministerio de Trabajo y Asuntos Sociales Subdirección General de Información Administrativa y Publicaciones, Colección Informes y Estudios. Serie Relaciones Laborales, Vol. 73.

Scholtens, B. and Fejit, M. (2017), "Facility Management groeit, kantorenmarkt krimpt. Hoe kan dit?", available at: https://www.linkedin.com/pulse/facility-management-groeit-kantorenmarktkrimpt-hoe-kan-feijt-mre/(accessed 11 November 2020).

Taylor, P. and Bain, P. (2006), "United by a common language? Trade union responses in the UK and India to call Centre offshoring", Antipode, Vol. 40 No. 1, pp. 131-154.

Teicher, J., Van Gramberg, B. and Holland, P. (2006), "Trade union responses to outsourcing in a neoliberal environment: a case study analysis of the Australian public sector", Asia Pacific Business Review, Vol. 12 No. 2, pp. 243-256.

Teichmann, S.A. (2009), "FM market size in Europe", European FM Insight, Vol. 11, pp. 5-7.

Traxler, F. (1995), "Farewell to labour market associations? Organized versus disorganized decentralization as a map for industrial relations", in Crouch, C. and Traxler, F. (Eds), Organized Industrial Relations in Europe: What Future?, Avebury, pp. 3-19.

Visser, J. (2009), The Quality of Industrial Relations and the Lisbon Strategy. European Commission, Industrial relations in Europe 2008, Office for Official Publications of the European Communities, pp. 45-72.

\section{Further reading}

Gumbrell-McCormick, R. and Hyman, R. (2013), Trade Unions in Western Europe. Hard Times, Hard Choices, Oxford University Press, Oxford.

Rigby, M. and Calavia, M.A. (2018), "Institutional resources as a source of trade union power in Southern Europe”, European Journal of Industrial Relations, Vol. 24 No. 2, pp. 129-143.

\section{Corresponding author}

Alejandro Godino can be contacted at: alejandro.godino@uab.es

For instructions on how to order reprints of this article, please visit our website:

www.emeraldgrouppublishing.com/licensing/reprints.htm

Or contact us for further details: permissions@emeraldinsight.com 